\title{
Heterogeneous Fleet Green Vehicle Routing Problem: A Literature Review
}

\author{
Nur Mayke Eka Normasari ${ }^{1}$, Nurul Lathifah ${ }^{2}$ \\ ${ }^{1,2}$ Departemen of Mechanical and Industrial Engineering, Universitas Gadjah Mada, Indonesia \\ Email: mayke@ugm.ac.id
}

Received: November 25, 2020; Accepted : April 19, 2021; Published : May 1, 2021

\begin{abstract}
Transportation, as a part of the supply chain process, contributes to carbon emission which leads to climate change and global warming. This environmental issue gives an impact to decisions regarding the supply chain of a company. One way to deal with this issue is by analyzing their vehicle routing problem. In this study, the issue about routing problems in green supply chain by considering the heterogeneous fleet is being discussed. One variant of Green Vehicle Routing Problem (GVRP) reviewed in this paper is about Heterogeneous Alternative Fuel Vehicles for Green Vehicle Routing Problem (HAFVGVRP). The purpose of this study is to review the development of GVRP with heterogeneous alternative fuel vehicles and the gap or state-of-the-art on existing researches. The review was classified according to the objectives, type of fleet, and solution used. Moreover, this study also presents the trend and direction of further research.

Keywords: Green Vehicle Routing Problem, Heterogeneous Fleet, Alternative Fuel Vehicles, Green Supply Chain,
\end{abstract} Literature Review

\section{ABSTRAK}

Transportasi yang merupakan bagian dari proses rantai pasok berkontribusi sebagai penghasil emisi karbon yang dapat menyebabkan perubahan iklim dan pemanasan global. Masalah lingkungan ini memberikan dampak terhadap pengambilan keputusan terkait rantai pasok dari suatu perusahaan. Salah satu cara untuk mengatasi masalah ini adalah dengan melakukan analisa pada masalah penentuan rute kendaraan dari perusahaan tersebut. Kajian ini membahas mengenai masalah penentuan rute dengan mempertimbangkan rantai pasok yang ramah lingkungan dengan mempertimbangkan armada yang heterogen. Salah satu varian dari Green Vehicle Routing Problem (GVRP) yang dibahas dalam kajian ini adalah mengenai Heterogeneous Alternative Fuel Vehicles for Green Vehicle Routing Problem (HAFVGVRP). Tujuan dari kajian ini adalah mengkaji pengembangan GVRP dengan kendaraan heterogen berbahan bakar alternatif atau non-konvensional dan mengetahui celah penelitian atau kebaruan dan pengembangan dari penelitian-penelitian yang ada. Kajian dilakukan dengan melakukan klasifikasi berdasarkan tujuan, jenis armada, dan pendekatan untuk solusi yang digunakan. Selain itu, kajian ini juga memperlihatkan tren dan arah penelitian kedepannya. Kata Kunci: Green Vehicle Routing Problem, Heterogeneous Fleet, Alternative Fuel Vehicles, Green Supply Chain, Literature Review

\section{INTRODUCTION}

Transportation plays an important role in the supply chain process of a company. Transportation is becoming increasingly more dynamic in line with the demand from the customers or company growth. In order to face problems that might exist in transportation sector, the concept of Vehicle Routing Problem (VRP) was developed. VRP concept was firstly being proposed in 1959 [1] and is still being proceeded to be developed with various variants and focuses. These various variants of VRP have been developed for different applications.

Corban emission can be produced by supply chain activities especially transportation [2,3]. Reducing carbon emission can be done by designing Vehicle Routing Problem (VRP), which then well known as Green Vehicle Routing Problem (GVRP). In GVRP, the concept of designing vehicle routes by considering the environmental problem is developed [4]. Research of GVRP has been conducted with various purposes. The purposes were to minimize carbon emission used in the routing [5, 6], minimize total travel distance [7, 8], and minimize total cost [6]. In order to achieve its environmental purposes, GVRP includes alternative fuel vehicles (AFVs) concept [9]. AFVs is one of the techniques that can be used to reduce the carbon which is one of the important aspects in GVRP theory.

Other than GVRP, Heterogeneous Fleet Vehicle Routing Problem (HFVRP) is also a classical variant of VRP. In homogeneous fleet, as a standard version of VRP, the capacity for all vehicles are same and usually based at a single depot [10]. Thus, HFVRP is more realistic because it considers the condition of transportation can used heterogeneous fleet or different types of vehicle. In HFVRP, there are several different types of 
vehicles with various capacities, fixed cost, and variable cost [11]. This heterogeneous fleet condition also could help in increasing the flexibility of distribution planning [12]. Most transportation companies used heterogeneous fleets in order to give flexibility for servicing the customers in different locations or with different demands [13]. Due to the condition of different capacities in each vehicle or heterogeneous fleet, this study will discuss the research development by considering this issue in environmental perspective.

This study aims to conduct a systematic literature review of relevant literature on VRP new variant which is being widely researched is about Heterogeneous Fleet Green Vehicle Routing Problem (HGVRP). This study is conducted because there is a lack of research that serves the roadmap of study on the development and in the field of HGVRP. Thus, this study will analyse the presence of research about the use of heterogeneous fleets with alternative fuel vehicles that concern about environmental issues on vehicle routing problems. In this study, the literatures are classified based on the objectives, type of fleet, and solution used for the development of GVRP variants. The contribution of this study is to present a literature review and classification of GVRP with heterogeneous alternative fuel vehicles. By conducting a literature review and classification of existing researches will help to find a gap or state-of-the-art and point out the opportunities within this topic for further research.

The remainder of this paper is organized as follows. Section 2 describes the methodology of literature review process used in this study. Section 3 presents the review of existing research on GVRP. In Section 4, the evolution of GVRP research especially with heterogeneous alternative fuel vehicles is explained. The trend and future direction of HGVRP research is shown in Section 5. Moreover, the paper ends in Section 6 by presenting the conclusion of this study.

\section{REVIEW METHODOLOGY}

\subsection{Source of Literature}

In this study, there are some databases used to compile the literature related with heterogeneous alternative fuel vehicles for GVRP. The databases utilized in this study include Elsevier, ScienceDirect, Springer, and IEEE. Besides, the literature also obtained from Google and Google Scholar according to the relevancy with the objective of this study. In the literature collection process, we found some types of publication sources as depicted in Table 1 .

Table 1. Main Source of Literature Based on Publication Year

\begin{tabular}{|c|c|c|c|c|c|c|c|c|c|c|c|}
\hline Source & ஓి & 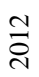 & $\stackrel{m}{\stackrel{N}{D}}$ & 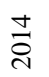 & $\frac{n}{\delta}$ & $\frac{o}{\delta}$ & $\frac{\sqrt{0}}{\circ}$ & $\stackrel{\infty}{\stackrel{\sim}{2}}$ & $\frac{\curvearrowright}{\stackrel{2}{~}}$ & ָิ & స్తేర \\
\hline Annals of Operation Research & & & & & & & & 1 & & & 1 \\
\hline Arabian journal for Science and Engineering & & & & & & & & & 1 & & 1 \\
\hline Computers and Industrial Engineering & & & & & & & 1 & & 1 & & 2 \\
\hline Computers and Operations Research & & & & & & & 1 & 1 & 4 & & 6 \\
\hline Electronics Notes in Discrete Mathematics & & & & & & & & 2 & & & 2 \\
\hline Energy Systems & & & & & & & 1 & & & & 1 \\
\hline Environmental Science and Pollution Research & & & & & 1 & & 1 & & & & 2 \\
\hline European Journal of Industrial Engineering & & & & & & & & & 1 & & 1 \\
\hline European Journal of Operational Research & & & & & & & 1 & & 2 & & 3 \\
\hline European Journal on Transportation and Logistics & & & & & & & & 1 & & & 1 \\
\hline Expert Systems with Applications & & & & & & & & 1 & 2 & 1 & 4 \\
\hline Flexible Services and Manufacturing Journal & & & 1 & & & & & & & & 1 \\
\hline International Journal of Production Economics & & & & & 1 & & & 1 & & & 2 \\
\hline International Journal of Vehicle Design & & & & & & 1 & & & & & 1 \\
\hline Journal of Automatica Sinica & & & & & & & & & 1 & & 1 \\
\hline Journal of Business Economics & & & & & & & & & 1 & & 1 \\
\hline Journal of Cleaner Production & & & & & & & 1 & 3 & $\begin{array}{l}1 \\
4\end{array}$ & 4 & $\begin{array}{c}1 \\
12\end{array}$ \\
\hline Journal of Industrial Engineering International & & & & & & 1 & & & & & 1 \\
\hline Logistics and Sustainable Transport & & & & & & & & & 1 & & 1 \\
\hline Mathematical Problems in Engineering & & & & & & & & & 1 & & 1 \\
\hline Optimization Letters & & & & & & & 1 & & & & 1 \\
\hline Soft Computing & & & & & & & & & 1 & & 1 \\
\hline Sustainability & & & & & & & & & & 1 & 1 \\
\hline Swarm and Evolutionary Computation & & & & & & & & & 1 & 1 & 2 \\
\hline TOP & & & & & & & & & 1 & & 1 \\
\hline Transportation Research Part B & & & & & & & & & 1 & 1 & 2 \\
\hline Transportation Research Part C & & & & & & 1 & & & 1 & & 2 \\
\hline Transportation Research Part D & & & & & & & 1 & & & & 1 \\
\hline Transportation Research Part E & & & & & & 1 & 2 & & & & 3 \\
\hline Others (Conference) & 1 & 3 & 1 & 3 & 1 & 2 & 5 & 5 & 7 & 3 & 31 \\
\hline
\end{tabular}

\subsection{Literature Search and Selection Process}

In the databases and other sources used to collect the existing literature, the searching process was conducted using a search phrase which are "green vehicle routing problem" and "heterogeneous fleet green vehicle routing problem". This exact phrase was used in order to reduce the number of irrelevant literatures for 
Heterogeneous Fleet Green Vehicle Routing Problem: A Literature Review

this study. By searching this phrase, there are around 133 literatures found from the academic databases and other sources.

After that, the literature selection was conducted. In the literature selection process, the literature must meet several criteria. The literature selection process for this study is confined to the literature that considered environmental issues and GVRP variants. In addition, the literature that would be selected is the literature that can be easily identified by its type of fleet and solution approach used. Besides, the literature must be written in English. The aim of this process is to help the review process for literatures that have been collected are easier to understand.

The process of literature selection began by reading the abstract of the literatures. The abstract of the literatures were read in order to determine its relevance with the objective of this study. Moreover, the literature that use languages other than English were eliminated. After reviewing all literatures, in the end there are 90 literatures found that contain the most relevant context with the objective in this study. These literatures are published between 2009 until 2020 as depicted in Figure 1. All of the literatures were recorded in a spreadsheet for further analysis and help in classifying processes.

\subsection{Classification Schemes}

One of the objectives in this study is to classify the literature related in GVRP. The literatures are classified based on the research objective, whether the literature has single-objective or multi-objective. After that, in each classification, the type of fleet and solution technique used for the literatures will be discussed.

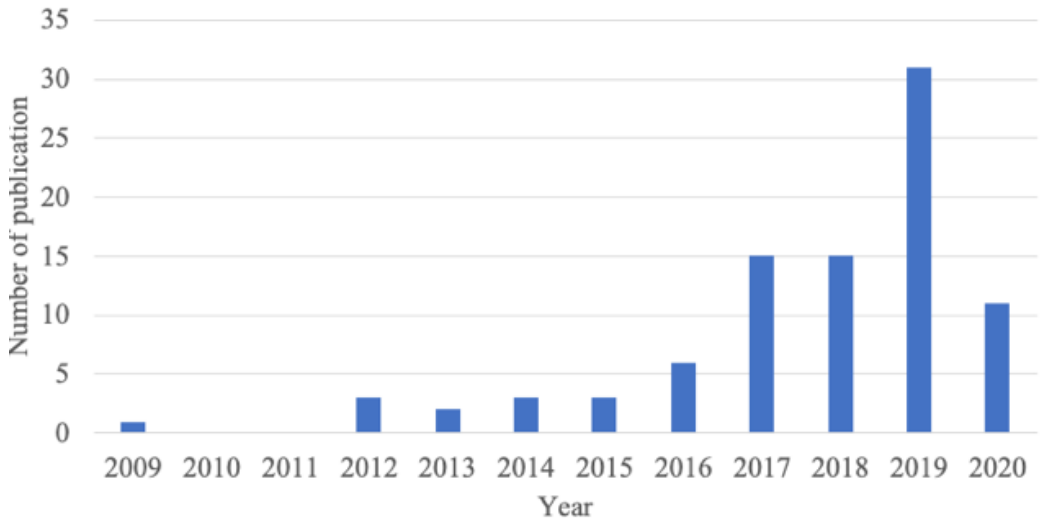

Figure 1. Distribution of literature based on publication year

\section{GREEN VEHICLE ROUTING PROBLEM}

Research about GVRP has been conducted by some researchers $[14,15,16]$. In GVRP, usually there are a set of customers, a set of refueling stations, and a fleet of AFVs to be analyzed [8]. Moreover, GVRP also can be applied in many sectors. One of the implementations for GVRP is solving routing problems for perishable products. The concept of GVRP is important for perishable products because this type of product must be transported as quickly as possible before they spoil [17]. Another implementation for GVRP concept is for vehicle scheduling and routing problems of airline ticketing companies [18]. In this condition, the company provides free services of picking customers up and taking the customers to airports. By considering the facilities provided by this company, the company needs to consider and optimize the emission footprint that produced and fuel consumption for their activities.

In GVRP, economic profit is not a primary objective [19]. The main concern is introducing vehicle transportation and routing models for alternative fuel vehicles (AFVs) which already consider environmental issues. The example of AFVs could be hybrid, electrical, and fuel cell vehicles [19]. GVRP is related with alternative fuel vehicles (AFVs) which by using AFVs can help in reducing carbon emission and fuel consumption. This condition will lead to minimizing fuel cost. However, using AFVs will lead to another problem. The problem is AFVs have limited tank capacity [20], and AFVs are required to visit alternative fuel stations (AFSs) for refueling [21]. On the other hand, since AFVs started to operate recently, the AFSs are still very few. Therefore, this condition makes routing decisions for AFVs getting more difficult to do [9].

There is some research that already tried to develop a concept in order to response AFVs problem. One of the examples is for electrical vehicles. Electrical vehicles that usually use batteries usually have a limited autonomy of battery, thus the possibility of recharging partially at available stations have been considered [22, 23]. However, a long charging time at station can give an impact to the route planning. This condition needs to be considered when short delivery time windows is becoming one of the constraints [24]. Thus, another solution that have been generated is by conducting battery swapping that helps in minimizing 
total travel time $[25,26]$. This solution has higher potential to reduce recharging times that leads to reduce overall cost [24].

The basic concept of GVRP only has a single depot. So that, the other variants of GVRP concept development is having a multi depot or known as multi-depot green vehicle routing problem (MDGVRP) [27, $28,29,30]$. Satisfactory-GVRP (SGVRP) is also another concept that has been developed. In this concept, maximizing customer satisfaction is also becoming one of the main objectives [31, 32]. GVRP can also be combined with scheduling problems in order to get a balanced environmental and economic costs by implementing effective vehicle routing and scheduling. This concept is known as green vehicle routing and scheduling problem (GVRSP) [33, 34, 35].

Concept of HFGVRP has been examined by some researchers. A comprehensive mixed integer linear programming model to formulate HFGVRP and scheduling problems by focusing on minimization of $\mathrm{CO}_{2}$ emission has been generated [33]. In that study, some considerations such as customer-vehicle assignment, route selection, and travel time scheduling have been analyzed. Other than that, the variant of HFGVRP has been developed using a fixed number of heterogeneous fleets with the purposes were to minimize distribution cost, fixed and variable fuel costs, the carbon emitted by the vehicles, total delivery tardiness, and customer dissatisfaction [34].

\section{GROWTH OF GVRP RESEARCH}

\subsection{GVRP with single-objective}

There are some variants of GVRP that have been developed by some researchers with singleobjective. One of the variants is green vehicle routing and scheduling problem (GVRSP) [5, 33]. In this concept, the scheduling for routing is also being considered, thus the output could be the minimization of carbon emission cost. Other than that, there is a research that tries to focus on capacitated AFS, in this concept, the capacity of each station is limited [36]. Thus, this could be a constraint for the model. The other development of GVRP is called HFGVRPTW or heterogeneous fleet green vehicle routing problem with time windows [43].

Some of the research only has one or single objective. One of the objectives that usually being considered in GVRP is to minimize total travel distance [8, 21, 36, 37, 38, 39, 40,41, 42]. Some of the research claimed that by minimizing total travel distance could give an indirect effect to reduce the operating cost. Other than minimizing total travel distance, another concern of the researches is about minimizing total carbon emission that produces $[33,35,43,44,45,46,47,48,49,50]$ and energy consumed from the routing process $[51,52]$. This issue is important to be examined in order to consider the environmental issues. The other important objective by implementing GVRP is also minimizing fuel consumption of the vehicle $[53,54,55$, $56,57]$.

From the literatures that have a single objective, then the classification based on the solution technique used in each literature also has been generated. The literature is classified into four classes which are exact method, heuristic, metaheuristic, and hybrid method. In exact method, there are some researchers who develop mixed integer linear programming (MILP) [39, 51, 59], MILP combine with branch-and-cut [37, 58], branchand-price [43], and develop mathematical model for problem being analyzed [5, 23, 38]. For heuristic methods, existing research used some techniques such as reduction procedure [37] and local search procedure $[8,44,45$, $23,24,60]$.

In metaheuristic method, previous researchers tried to implement some technique such as neighborhood search [33], genetic algorithm (GA) [24, 44, 50, 61], tabu search [47, 48], simulated annealing (SA) [42], and ant colony optimization (ACO) [21, 45, 52]. Other than that, there are also some hybrid method used such as exact-metaheuristic by combining set covering model with iterated local search (ILS) [5], heuristic-heuristic by combining column (CG) generation and adaptive large neighborhood search (ALNS) [26], heuristic-metaheuristic by combining large neighborhood search (LNS) with ACO [45], and metaheuristic-metaheuristic by combining GA and SA [62].

\subsection{GVRP with multi-objective}

One concept for GVRP with multi-objective is emission-based heterogeneous fixed-fleet vehicle routing problem (EHFFVRP) [34, 64]. It is a new variant of the heterogeneous fixed fleet vehicle routing problem (HFFVRP), in which a fleet consists of a fixed number of vehicles with different capacities, fixed costs and variable costs [64].

Other than single-objective, researchers that try to develop GVRP concepts also use multi-objective. The example of this multi-objective are minimizing fuel consumption and optimizing customer satisfaction [63], minimizing fuel consumption and carbon emission [64, 65, 66], minimizing total cost and carbon emission $[67,68,69,70,71]$, minimizing total travel distance and carbon emission $[72,74,78,80]$ or fuel consumption 
Heterogeneous Fleet Green Vehicle Routing Problem: A Literature Review

[73, 79, 81], minimizing total travel distance and energy consumed [75, 76, 82], minimizing cost and air pollution [87], and improving energy efficiency and customer satisfaction [77].

For GVRP with multi-objective, the literature also classified into four classes which are exact method, heuristic, metaheuristic, and hybrid method. There are some researchers who develop GVRP with multiobjective using exact methods. The examples of this method are $\varepsilon$-Constraint $[9,86]$, mathematical model and try to solve model by using CPLEX software [83], mix integer programming [84], and MILP [85]. For heuristic method, existing researches used Clarke and Wright Savings Heuristic Algorithm (CWSHA) and Sweep Algoritm (SwA) [28], multi-objective evolutionary algorithm (MOEA) [88], planning algorithm and using MOBILE5 software to help in calculating emission [14].

Moreover, for metaheuristic method, previous research used split-based adaptive tabu search (SATS) [64], time varying (TVa) and particle swarm optimization with greedy mutation operator (PSOGMO) [89], non-dominated sorting genetic algorithm II (NSGA II) [32, 93], Ant colony optimization (ACO) [90], variable neighborhood search [94], variable neighborhood tabu search algorithm [91], and GA [92]. Besides, in multiobjective GVRP there are some hybrid methods that have been implemented such as exact-exact, exactmetaheuristic, and heuristic-metaheuristic.

\section{TRENDS AND FUTURE DIRECTIONS OF HGVRP}

Table 2 shows the VRP variant researches from 2009 until 2020. It is depicted that there are some researches that used homogeneous fleet. Besides, the number of researches that consider heterogeneous fleet is still growing. However, the research is still limited and developed, thus some further research can try to adopt heterogeneous fleet in their research because this concept helps in increasing the flexibility of vehicles. Moreover, heterogeneous fleets should be applied because it is more realistic than other homogeneous vehicle routing problem variants.

In addition, from the review process, it can be seen that some research focuses on electric vehicle as the alternative fuel vehicle. On the other hand, there are some other AFVs that can be used. Thus, further work can explore other type of AFVs to get more comparison within the type of AFVs. Further researches may explore the implementation of heterogeneous fleet in different type of AFVs. The further research also may explore the trade-off between the use of different type of fleet or solution approach with a single or multiobjective of the research.

\begin{tabular}{|c|c|c|}
\hline & & Research \\
\hline \multirow{2}{*}{ हैं } & Homogeneous fleet & $\begin{array}{l}73,65,19,80,38,44,74,75,66,92,71,58,18,20,37,90,62,78,81,15,70,86,16,100,89, \\
45,88,14,24,21,85,52,57,87,50,9,63,28,36,96,46,47,61,77,68,79,82,39,51,40, \\
97,99,41,42,29,30,25,60,17,93,94,49\end{array}$ \\
\hline & Heterogeneous fleet & $\begin{array}{l}53,31,33,54,84,55,95,35,98,5,64,59,27,67,8,43,32,76,69,91,22,23,26,56,48,72, \\
83,34\end{array}$ \\
\hline \multirow{4}{*}{ :气 } & Exact method & $\begin{array}{l}73,65,19,53,38,66,92,31,33,58,37,84,90,35,78,81,86,98,5,64,59,27,85,9,67,63, \\
36,43,76,79,82,91,39,22,51,23,40,26,48,99,41,72,83,34,25,60\end{array}$ \\
\hline & Heuristics & $38,44,75,18,20,37,90,55,70,100,89,45,88,14,24,8,28,46,91,23,56,60$ \\
\hline & Metaheuristics & $\begin{array}{l}19,80,44,74,66,92,71,33,18,90,62,78,81,89,64,45,27,24,21,52,50,67,63,28,32, \\
96,47,61,77,68,69,91,22,48,99,41,42,34,30,60,93,94,49\end{array}$ \\
\hline & Hybrid & $33,54,18,62,98,5,45,21,57,9,67,63,28,48,29,30,25$ \\
\hline
\end{tabular}

\section{CONCLUSION}

This study conducted a literature review of current research about green vehicle routing problems. The literatures were collected from scientific journals, proceedings, and academic articles that focus on GVRP. There are more than 133 literatures that discussed about GVRP and its development. However, in this study there are only 90 literatures included to be analyzed. These literatures have been reviewed and classified in order to determine the further research that can be discussed.

Based on the literature review, some of current research on GVRP used homogeneous fleets as the transportation of their supply chain. However, some of the researchers are trying to develop research about the use of heterogeneous fleets. Even though there have been several researches that used multi-objective in their research, most of the studies are used single objective. Thus, further research should consider the research objective that should be used, especially when the certain objective has been used and analysed in the previous research. Besides, there are some solution approaches used in the research on GVRP including exact method, heuristics, metaheuristics, and hybrid.

In short, this study could give a better understanding about the state-of-the-art of research on HAFVGVRP. Thus, based on the literature review, the further research should try to combine and develop the use of heterogeneous fleet particularly alternative fuel vehicles with the solution approaches provided. Besides, this study has limitations including the limited size of survey. This study only covers a limited number of 
literatures while there are some other publications that might discuss the development of GVRP. There also might be some publications about GVRP that is published in databases or sources used in this study. Therefore, in order to strengthen this study, further research might extend the scale of the review and conduct a more detail classification.

\section{ACKNOWLEDGMENTS}

This research was supported by the Department of Mechanical and Industrial Engineering (DTMI), Faculty of Engineering (FT), Gadjah Mada University (UGM) under grant Hibah DTMI No. 417/UN1/FTK/SK/HK/2020.

\section{REFERENCES}

[1] G. B. Dantzig and J. H. Ramser, "The truck dispatching problem,” Management Science, vol. 6, no. 1, pp. 80-91, 1959.

[2] S. Treitl, P. C. Nolz, and W. Jammernegg, "Incorporating environmental aspects in an inventory routing problem. A case study from the petrochemical industry," Flexible Services and Manufacturing Journal, vol. 26, pp.143-169, 2014.

[3] G. J. L. Micheli and F. Mantella, "Modelling an environmentally-extended inventory routing problem with demand uncertainty and a heterogeneous fleet under carbon control policies," International Journal of Production Economics, vol. 204, pp. 316-327, 2018.

[4] N. M. E. Normasari, V.F. Yu, C. Bachtiyar, and Sukoyo, "A simulated annealing heuristic for the capacitated green vehicle routing problem," Mathematical Problems in Engineering, 2019.

[5] M. R. S. Matos, Y. Frota, and L. S. Ochi, "Green vehicle routing and scheduling problem with split delivery," Electronic Notes in Discrete Mathematics, vol. 69, pp. 13-20, 2018.

[6] Y. Wang, K. Assogba, J. Fan, M. Xu, Y. Liu, and H. Wang, "Multi-depot green vehicle routing problem with shared transportation resource: Integration of time-dependent speed and piecewise penalty cost," Journal of Cleaner Production, vol. 232, pp. 12-29, 2019.

[7] M. Bruglieri, S. Mancini, and O. Pisacane, "The green vehicle routing problem with capacitated alternative fuel stations," Computers and Operations Research, vol. 112, pp. 1-12, 2019.

[8] J. Andelmin and E. Bartolini, "A Multi-start local search heuristic for the green vehicle routing problem based on a multigraph reformulation," Computers and Operations Research, vol. 109, pp. 43-63, 2019.

[9] O. Kabadurmuş, M. S. Erdogan, Y. Ozkan, and M. Koseoglu, "A multi-objective solution of green vehicle routing problem," Logictics and Sustainable Transport, vol. 10, no. 1, pp. 31-44, 2019.

[10] F. Li, B. Golden, and E. Wasil, "A record-to-record travel algorithm for solving the heterogeneous fleet vehicle routing problem," Computers \& Operations Research, vol. 34, pp. 2734-2742, 2007.

[11] M. Gendreau, G. Laporte, C. Musaraganyi, and D. D. Taillard, "A Tabu Search Heuristic for the Heterogeneous Fleet Vehicle Routing Problem,” Computers \& Operations Research, vol. 26, pp. 1153-1173, 1999.

[12] P. H. V. Penna, A. Subramanian, and L. S. Ochi, "An iterated local search heuristic for the heterogeneous fleet vehicle routing problem," Journal of Heuristics, vol. 19, pp. 201-232, 2013.

[13] A. Hoff, H. Andersson, M. Christiansen, G. Hasle, A. Løkketangen, "Industrial aspects and literature survey: Fleet composition and routing," Computers and Operation Research, vol. 37, no. 12, pp. 2041-2061, 2010.

[14] J. Leu, A. Krischke, Y. Lee, L. J. Lee and Y. Huang, "A Green Vehicle Routing Method for the Regional Logistics Center," 2018 IEEE International Conference on Industrial Engineering and Engineering Management (IEEM), pp. 71-75, 2018.

[15] G. K. D.Saharidis, "Environmental Externalities Score: a new emission factor to model green vehicle routing problem," Energy Systems, vol. 8, pp. 673-691, 2017.

[16] M. Turkensteen, "The accuracy of carbon emission and fuel consumption computations in green vehicle routing," European Journal of Operational Research, vol. 262, pp. 647-659, 2017.

[17] F. E. Zulvia, R. J. Kuo, and D. Y. Nugroho, "A many-objective gradient evolution algorithm for solving a green vehicle routing problem with time windows and time dependency for perishable products," Journal of Cleaner Production, vol 242, 2020.

[18] H. Gang, F. Meiling, Z. Hainan and S. Junqing, "Research on green vehicle scheduling problem of free picking up and delivering customers for airlines ticketing company," 2016 Chinese Control and Decision Conference (CCDC), pp. 6192-6197, 2016.

[19] A. Omidvar and R. Tavakkoli-Moghaddam, "Sustainable vehicle routing: Strategies for congestion management and refueling scheduling," IEEE International Energy Conference and Exhibition (ENERGYCON), pp. 1089-1094, 2012.

[20] A. Montoya, C. Gueret, J. E. Mendoza, and J. G. Villegas, "A multi-space sampling heuristic for the green vehicle routing problem," Transportation Research Part C, vol. 70, pp. 113-128, 2016.

[21] S. Zhang, Y. Gajpal, and S. S. Appadoo, "A meta-heuristic for capacitated green vehicle routing problem," Annals of Operations Research, vol. 269, pp. 753-771, 2018.

[22] G. Macrina, G. Laporte, F. Guerriero, and L. D. P. Pugliese, "An enery-efficient green-vehicle routing problem with mixed vehicle fleet, partial battery recharging, and time windows," European Journal of Operational Research, vol. 276, pp. 971-982, 2019. 
Heterogeneous Fleet Green Vehicle Routing Problem: A Literature Review

[23] G. Macrina, L. D. P. Pugliese, F. Guerriero, and G. Laporte, "The green mixed fleet vehicle routing problem with partial battery recharging and time windows," Computers and Operations Research, vol. 101, pp. 183-199, 2019.

[24] A. Verma, "Electric vehicle routing problem with time windows, recharging stations, and battery swapping stations," European Journal on Transportation and Logistics, vol. 7, pp. 415-451, 2018.

[25] R. Raeesi and K. G. Zografos, "The electric vehicle routing problem with time windows and synchronised mobil battery swapping," Transportation Research Part B, vol. 140, pp. 101-129, 2020.

[26] W. Jie, J. Yang, M. Zhang, and Y. Huang, "The two-echelon capacitated electric vehicle routing problem with battery swapping stations: Formulation and efficient methodology," European Journal of Operational Research, vol. 272, pp. 879-904, 2019.

[27] A. Dao-Tuan and A. Nguyen-Thi-Ngoc, "A multi-criteria optimization model for emission-concerned multi-depot vehicle routing problem with heterogeneous fleet," 2018 International Conference on Applied Smart Systems (ICASS), pp. 1-7, 2018.

[28] Y. Wang, K. Assogba, J. Fan, M. Xu, Y. Liu, and H. Wang, "Multi-depot green vehicle routing problemwith shared transportation resource: Integration of time-dependent speed and piecewise penalty cost," Journal of Cleaner Production, vol 232, pp. 12-29, 2019.

[29] B. Peng, L. Wu, Y. Yi, and X. Chen, "Solving the multi-depot green vehicle routing problem by a hybrid evolutionary algorithm," vol. 12, no. 5, 2020.

[30] M. K. Mehlawat, P. Gupta, A. Khaitan and W. Pedrycz, "A Hybrid Intelligent Approach to Integrated Fuzzy Multiple Depot Capacitated Green Vehicle Routing Problem With Split Delivery and Vehicle Selection," IEEE Transactions on Fuzzy Systems, vol. 28, no. 6, pp. 1155-1166, 2020.

[31] M. Afshar-Bakeshloo, A. mehrabi, H. Safari, M. Maleki, and F. Jolai, "A green vehicle routing problem with customer satisfaction criteria," Journal of Industrial Engineering International, vol. 12, pp. 529-544, 2016.

[32] S. F. Ghannadpour and A. Zarrabi, "Multi-objective heterogeneous vehicle routing and scheduling problem with energy minimizing," Swarm and Evolutionary Computation, vol. 44, pp. 728-747, 2019

[33] Y. Xiao and A. Konak, "The heterogeneous green vehicle routing and scheduling problem with time-varying traffic congestion," Transportation Research Part E, vol. 88, pp. 146-166, 2016.

[34] M. Ganji, H. Kazemipoor, S. M. H. Molana, and S. M. Sajadi, "A green multi-objective integrated scheduling of production and distribution with heterogeneous fleet vehicle routing and time windows," Journal of Cleaner Production, vol. 259, 2020.

[35] N. Nabil, H. A. Farouk and K. S. El-Kilany, "Green vehicle routing and scheduling problem with optimized travel speed," 2017 IEEE International Conference on Industrial Engineering and Engineering Management (IEEM), pp. 1057-1061, 2017.

[36] M. Bruglieri, S. Mancini, and O. Pisacane, "The green vehicle routing problem with capacitated alternative fuel stations," Computers and Operations Research, vol. 112, 2019.

[37] V. Leggieri and M. Haouari, "A practical solution approach for the green vehicle routing problem," Transportation Research Part E, vol. 104, pp. 97-112, 2017.

[38] M. Yasin and V. F. Yu, "A simulated annealing heuristic for the green vehicle routing problem," Proceedings of the Institute of Industrial Engineers Asian Conference 2013, pp. 1261-1269, 2013.

[39] M. Bruglieri, S. Mancini, and O. Pisacane, "'More efficient formulations and valid inequalities for the green vehicle routing problem," Transportation Research Part C, vol. 105, pp. 283, 2019.

[40] M. Bruglieri, S. Mancini, F. Pezzella and O. Pisacane, "A path-based solution approach for the Green Vehicle Routing Problem," Computers and Operations Research, vol. 103, pp. 109-122, 2019.

[41] T. Erdelic, T. Caric, M. Erdelic, and L. Tisljaric, "Electrical vehicle routing problem with single or multiple recharges," 13th International Scientific Conference on Sustainable, Modern, and Safe Transport (TRANSCOM 2019), vol. 40, pp. 217-224, 2019.

[42] N. M. E Normasari, V. F. Yu, C. Bachtiyar, and Sukoyo, "A Simulated Annealing Heuristic for the Capacitated Green Vehicle Routing Problem," Mathematical Problems in Engineering, 2019.

[43] Y. Yu, S. Wang, J. Wang, and M. Huang, "A branch-and-price algorithm for the heterogeneous fleet green vehicle routing problem with time windows," Transportation Research Part B, vol. 122, pp. 511-527, 2019

[44] R. Ayadi, A. E. ElIdrissi, Y. Benadada and A. El Hilali Alaoui, "Evolutionary algorithm for a Green vehicle routing problem with multiple trips," International Conference on Logistics Operations Management, pp. 148-154, 2014.

[45] E. Messaoud, A. El Bouzekri El Idrissi and A. E. Alaoui, "The green dynamic vehicle routing problem in sustainable transport," 2018 4th International Conference on Logistics Operations Management (GOL), pp. 1-6, 2018.

[46] D. Tayachi and H. Boukadi, "A variable neighborhood search to reduce carbon dioxide emissions in the capacitated vehicle routing problem," 2019 6th International Conference on Control, Decision and Information Technologies (CoDIT), pp. 297-301, 2019.

[47] P. Kirci, "A Novel Model for Vehicle Routing Problem with Minimizing CO2 Emissions," 2019 3rd International Conference on Advanced Information and Communications Technologies (AICT), pp. 241-243, 2019.

[48] J. Wang, S. Yao, J. Sheng, and H. Yang, "Minimizing total carbon emissions in an integrated machine scheduling and vehicle routing problem," Journal of Cleaner Production, vol. 229, pp. 1004-1017, 2019.

[49] D. Trachanatzi, M. Rigakis, M. Marinaki, and Y. Marinakis, "A firefly algorithm for the environmental prizecollecting vehicle routing problem," Swarm and Evolutionary Computation, vol. 57, 2020.

[50] P. R. O. Costa, S. Mauceri, P. Carroll, and F. Pallonetto, "A Genetic Algorithm for a Green Vehicle Routing Problem," Electronic Notes in Discrete Mathematics, vol. 64, pp. 65-74, 2018.

[51] Y. Xiao, X. Zuo, I. Kaku, S. Zhou, and X. Pan, "Development of energy consumption optimization model for the electric vehicle routing problem with time windows," Journal of Cleaner Production, vol. 225, pp. 647-663, 2019. 
[52] S. Zhang, Y. Gajpal, S. S. Appadoo, and M. M. S. Abdulkader "Electric vehicle routing problem with recharging stations for minimizing energy consumption," International Journal of Production Economics, vol. 203, pp. 404413, 2018.

[53] H. W. Kopfer, J. Schonberger, and H. Kopfer, "Reducing greenhouse gas emissions of a heterogeneous vehicle fleet," Flexible Services and Manufacturing Journal, vol. 25, no. 3, 2013.

[54] S. Ene, I. Kucukoglu, A. Aksoy, and N. Ozturk, "A hybrid metaheuristic algorithm for the green vehicle routing problem with heterogeneous fleet," International Journal of Vehicle Design, vol. 71, pp. 75-102, 2016.

[55] M. Ziebuhr, T. Buer and H. Kopfer, "A column generation-based heuristic for a green vehicle routing problem with an unlimited heterogeneous fleet," 2017 IEEE Symposium Series on Computational Intelligence (SSCI), pp. 1-8, 2017.

[56] K. L. Soon, J. M. Lim, R. Parthiban, and M. C. Ho, "Proactive eco-friendly pheromone-based green vehicle routing for multi-agent systems," Expert Systems with Applications, vol 121, pp. 324-337, 2019

[57] Y. Niu, Z. Yang, P. Chen, and J. Xiao, "Optimizing the green open vehicle routing problem with time windows by minimizing comprehensive routing cost," Journal of Cleaner Production, vol. 171, pp. 962-971, 2018

[58] K. Sundar, S. Venkatachalam and S. Rathinam, "Formulations and algorithms for the multiple depot, fuelconstrained, multiple vehicle routing problem," American Control Conference (ACC), pp. 6489-6494, 2016.

[59] N. Mouhrim, A. El Hilali Alaoui and J. Boukachour, "Vehicle routing problem with mixed fleet of electric and conventional vehicles under emissions allowances," 2018 4th International Conference on Logistics Operations Management (GOL), pp. 1-5, 2018.

[60] J. Lu, Y. Chen, J. Hao, and R. He, "The Time-dependent Electric Vehicle Routing Problem: Model and solution," Expert Systems with Applications, vol. 161, 2020.

[61] H. Jammeli, M. Argoubi and H. Masri, "Genetic Algorithm for a Stochastic Programming Model of the Green Household Waste Transportation Problem," 2019 8th International Conference on Modeling Simulation and Applied Optimization (ICMSAO), pp. 1-6, 2019.

[62] M. Rabbani, Z. Tahaei, H. Farrokhi-Asl and N. A. Saravi, "Using meta-heuristic algorithms and hybrid of them to solve multi compartment Vehicle Routing Problem," 2017 IEEE International Conference on Industrial Engineering and Engineering Management (IEEM), pp. 1022-1026, 2017.

[63] Z. Xu, A. Elomri, S. Pokharel, and F. Mutlu, "A model for capacitated green vehicle routing problem with the timevarying vehicle speed and soft time windows," Computers and Industrial Engineering, vol 137, 2019.

[64] J. Li, D. Wang, and J. Zhang, "Heterogeneous fixed fleet vehicle routing problem based on fuel and carbon emissions," Journal of Cleaner Production, vol. 201, pp. 896-908, 2018.

[65] Y. Huang, C. Shi, L. Zhao and T. V. Woensel, "A study on carbon reduction in the vehicle routing problem with simultaneous pickups and deliveries," Proceedings of 2012 IEEE International Conference on Service Operations and Logistics, and Informatics, pp. 302-307, 2012.

[66] I. Kucukoglu, S. Ene, A. Aksoy, and N. Ozturk, "A memory structure adapted simulated annealing algorithm for a green vehicle routing problem," Environmental Science and Pollution Research, vol. 22, pp. 3279-3297, 2015.

[67] N. Rezaei, S. Ebrahimnejad, A. Moosavi, and A. Nikfarjam, "A green vehicle routing problem with time windows considering the heterogeneous fleet of vehicles: Two metaheuristic algorithms," European Journal of Industrial Engineering, vol. 13, no. 4, pp. 507-535, 2019.

[68] G. Y. Qin, F. M. Tao and L. X. Li, "A Green Vehicle Routing Optimization Model with Adaptive Vehicle Speed Under Soft Time Window," 2019 IEEE International Conference on Industrial Engineering and Engineering Management (IEEM), pp. 1-5, 2019.

[69] M. Alinaghian and M. Zamani, "A bi-objective fleet size and mix green inventory routing problem, model, and solution method," Soft Computing, vol. 23, pp. 1375-1391, 2019.

[70] M. Soysal and M. Cimen, "A simulation based restricted dynamic programming approach for the green time dependent vehicle routing problem," Computers and Operations Research, vol. 88, pp. 297-305, 2017.

[71] E. Jabir, V. V. Panicker, and R. Sridharan, "Multi-objective optimization model for a green vehicle routing problem," XVIII Annual International Conference of the Society of Operations Management (SOM-14), vol. 189, pp. 33-39, 2015.

[72] H. H. Amer, H. A. Farouk, and K. S. El-Kilany, "Heterogeneous green vehicle routing problem with hierarchical objectives: Case study," Proceedings of the International Conference on Industrial Engineering and Operations Management, pp. 1289-1300, 2020.

[73] Y. Peng and X. Wang, "Research on a Vehicle Routing Schedule to Reduce Fuel Consumption," International Conference on Measuring Technology and Mechatronics Automation, pp. 825-827, 2009

[74] E. E. Adiba, E. A. Aahmed and B. Youssef, "The green capacitated vehicle routing problem: Optimizing of emissions of greenhouse gas," International Conference on Logistics Operations Management, pp. 161-167, 2014.

[75] F. Baouche, R. Billot, R. Trigui and N. E. El Faouzi, "Electric Vehicle green routing with possible enroute recharging," 17th International IEEE Conference on Intelligent Transportation Systems (ITSC), pp. 2787-2792, 2014.

[76] V. F. Yu, P. Jodiawan, A. Gunawan and A. T. Widjaja, "A Mathematical Programming Model for the Green Mixed Fleet Vehicle Routing Problem with Realistic Energy Consumption and Partial Recharges," 2019 IEEE International Conference on Industrial Engineering and Engineering Management (IEEM), pp. 1339-1343, 2019.

[77] Y. Su and Q. Fan, "The Green Vehicle Routing Problem from a Smart Logistics Perspective," IEEE Access, vol. 8, pp. 839-846, 2020.

[78] B. Abdoli, S. A. MirHassani, and F. Hooshmand, "Model and algorithm for bi-fuel vehicle routing problem to reduce GHG emissions," Environmental Science and Pollution Research, vol. 24, 2017. 
Heterogeneous Fleet Green Vehicle Routing Problem: A Literature Review

[79] A. Eydi and H. Alavi, "Vehicle routing problem in reverse logistics with split demands of customers and fuel consumption optimization," Arabian Journal for Science and Engineering, vol. 44, pp. 2641-2651, 2019.

[80] J. Jemai, M. Zekri, and K. Mellouli, "An NSGA-II Algorithm for the Green Vehicle Routing Problem," Hao JK., Middendorf M. (eds) Evolutionary Computation in Combinatorial Optimization. EvoCOP 2012. Lecture Notes in Computer Science, vol. 7245, 2012.

[81] N. Norouzi, M. Sadegh-Amalnick, and R. Tavakkoli-Moghaddam, "Modified particle swarm optimization in a time-dependent vehicle routing problem: minimizing fuel consumption," Optimization Letters, vol. 11, pp. 121134, 2017.

[82] H. Kopfer and B. Vornhusen, "Energy vehicle routing problem for differently sized and powered vehicles," Journal of Business Economics, vol. 89, pp. 793-821, 2019.

[83] M. A. Masmoudi, K. A. Kuzmicz, E. Pesch, E. Demir, and M. Hosny, "Container truck transportation routing as a Mixed Fleet Heterogeneous Dial-a-Ride Problem," 9th International Conference on Engineering, Project, and Production Management, vol. 312, 2020.

[84] C. Cheng, P. Yang, M. Qi, and L. Rousseau, "Modeling a green inventory routing problem with a heterogeneous fleet," Transportation Research Part E, vol. 97, pp. 97-112, 2017.

[85] S. Madankumar and C. Rajendran, "Mathematical models for green vehicle routing problems with pickup and delivery: A case of semiconductor supply chain," Computers and Operations Research, vol. 89, pp. 183-192, 2018.

[86] E. M. Toro, J. F.Franco, M. G. Echeverri, and F. G. Guimaraes, "A multi-objective model for the green capacitated location-routing problem considering environmental impact," Computers and Industrial Engineering, vol. 110, pp. 114-125, 2017.

[87] H. Soleimani, Y. Chaharlang, and H. Ghaderi, "Collection and distribution of returned-remanufactured products in a vehicle routing problem with pickup and delivery considering sustainable and green criteria," Journal of Cleaner Production, vol. 172, pp. 960-970, 2018.

[88] C. Wu, T. Visutarrom and T. Chiang, "Green Vehicle Routing Problem: The Tradeoff between Travel Distance and Carbon Emissions," 2018 15th International Conference on Control, Automation, Robotics and Vision (ICARCV), pp. 1659-1664, 2018.

[89] G. Poonthalir and R. Nadarajan, "A fuel efficient green vehicle routing problem with varying speed constraint (FGVRP)," Expert Systems with Applications, vol. 100, pp. 131-144, 2018.

[90] I. Kaabachi, D. Jriji and S. Krichen, "An improved ant colony optimization for green multi-depot vehicle routing problem with time windows," 2017 18th IEEE/ACIS International Conference on Software Engineering, Artificial Intelligence, Networking and Parallel/Distributed Computing (SNPD), pp. 339-344, 2017.

[91] J. C. Molina, I. Eguia, and J. Racero, "Reducing pollutant emissions in a waste collection vehicle routing problem using a variable neighborhood tabu search algorithm: a case study," TOP, vol. 27, pp. 253-287, 2019.

[92] A. Tiwari and P. Chang, "A block recombination approach to solve green vehicle routing problem," International Journal of Production Economics, vol 164, pp. 379-387, 2015.

[93] W. Liao, L. Zhang, and Z. Wei, "Multi-objective green meal delivery routing problem based on a twostage solution strategy," Journal of Cleaner Production, vol. 258, 2020.

[94] X. Ren, H. Huang, S. Feng, and G. Liang, "An improved variable neighborhood search for bi-objective mixed energy fleet vehicle routing problem," Journal of Cleaner Production, vol. 275, 2020.

[95] X. Liu, M. Qi and C. Cheng, "Green vehicle routing problem with path flexibility," 2017 IEEE International Conference on Industrial Engineering and Engineering Management (IEEM), pp. 1037-1041, 2017.

[96] L. Wang and J. Lu, "A memetic algorithm with competition for the capacitated green vehicle routing problem," Journal of Automatica Sinica, vol. 6, no. 2, pp. 516-526, 2019.

[97] G. Poonthalir and R. Nadarajan, "Green vehicle routing problem with queues," Expert Systems with Applications, vol 138, 2019.

[98] Y. Xiao and A. Konak, "A genetic algorithm with exact dynamic programming for the green vehicle routing \& scheduling problem," Journal of Cleaner Production, vol. 167, pp. 1450-1463, 2017.

[99] X. Zuo, Y. Xiao, M. You, I. Kaku, and Y. Xu, "A new formulation of the electric vehicle routing problem with time windows considering concave nonlinear charging function," Journal of Cleaner Production, vol. 236, 2019.

[100] M. Cimen and M. Soysal, "Time-dependent green vehicle routing problem with stochastic vehicle speeds: An approximate dynamic programming algorithm," Transportation Research Part D, vol. 54, pp. 82-98, 2017. 